\title{
OS FUNDAMENTOS POLÍTICO-FILOSÓFICOS DA PROPRIEDADE MODERNA, SUAS RUPTURAS E A FUNÇÃO SOCIAL
}

\author{
Cloves dos Santos Araújo ${ }^{1}$
}

\begin{abstract}
RESUMO
A modernidade ocidental, rompendo com a fé, a tradição e formas coletivas de relacionamento com a terra, introduziu nos sistemas jurídicos um conceito de propriedade centrada não no uso coletivo, como acontecia na antiguidade, mas, sobretudo, na apropriação individual e na mercantilização. John Locke, buscando justificar filosoficamente este modo de apropriação da natureza pelo indivíduo, elege o trabalho como fio condutor. A propriedade, com a codificação moderna, passa a incorporar os ordenamentos jurídicos como direito individual exclusivo. Todavia, a partir da segunda década do Século XX, a propriedade tem seu conteúdo modificado, passando a ter o encargo de atender à função social.
\end{abstract}

Palavras-chave: Modernidade. Propriedade. Trabalho. Função Social.

\section{INTRODUÇÃO}

Este artigo tem por objetivo analisar a propriedade na perspectiva dos aspectos norteadores do discurso filosófico da modernidade. Ao longo do trabalho foi realizada uma revisão da literatura que considerou duas categorias conceptuais sobre propriedade - a antiga e a moderna. ${ }^{2}$ Enquanto no mundo antigo, como regra, a propriedade está ligada ao uso, à fé religiosa, às tradições, a modernidade ocidental introduz uma concepção individualista, transformando a terra em mercadoria.

Ao longo do texto dialogamos acerca das profundas modificações no cotidiano das relações sociais que, na modernidade, situam o indivíduo como ponto de

\footnotetext{
${ }^{1}$ Mestre em Direito pela UNB, ex-bolsista da Fundação Ford/Carlos Chagas, Professor da UEFS e da UNEB, membro do Grupo de Pesquisa "O Direito Achado na Rua" - UNB e do Grupo de Pesquisa "Terra, Território, Direito e Conflitos Coletivos" - UEFS, membro da Rede Nacional de Advogados Populares RENAP, membro da Associação de Advogados de Trabalhadores Rurais no Estado da Bahia - AATR.

${ }^{2}$ Este estudo, ressalvadas as modificações realizadas, integra parte da nossa dissertação de mestrado defendida na Faculdade de Direito da Universidade de Brasília, sob o título "O Judiciário e os conflitos agrários no Brasil”.
} 
partida do relato político. ${ }^{3} \mathrm{O}$ Estado passa a ter como finalidade precípua a garantia da liberdade, igualdade e da propriedade, assumindo esta última a centralidade.

Para uma melhor caracterização da moderna concepção de propriedade, realizamos um estudo dos fundamentos político-filosóficos, com embasamento na tese de John Locke, notadamente na relação que o mencionado pensador estabelece entre o trabalho e a propriedade. Na doutrina nacional as reflexões feitas por Carlos Frederico Marés, além de outros, foram de relevância fundamental para este estudo.

No paradigma do Estado Moderno, cabe ao Judiciário a garantia do exercício desse direito, ainda que excluindo a imensa maioria do acesso, sem nenhuma preocupação também com os aspectos socioambientais.

Como resultado de intensas lutas sociais e de concepções filosóficas contrárias ao discurso liberal, mudanças significativas foram introduzidas no conceito de propriedade e incorporadas nas mais diversas Constituições. Todavia, as mencionadas mudanças não foram efetivadas nos países da semiperiferia e da periferia do sistema mundo, exercendo o Judiciário, nesses países, um importante papel na manutenção da propriedade da terra no seu sentido consolidado no século XIX.

\section{A PROPRIEDADE ANTIGA}

O primeiro homem que, tendo murado um terreno, se lembrou de dizer: isto é $\boldsymbol{m e u}$, e encontrou pessoas simples que o acreditaram, foi o verdadeiro fundador da sociedade civil. Quantos crimes, quantas guerras, quantos assassínios, quantas misérias e horrores não teria evitado ao gênero humano aquele que, arrancando as pedras ou tapando o fosso, gritasse para os seus semelhantes: "Tende cuidado, não escuteis esse impostor; estais perdidos se esqueceis que os frutos são de todos e a terra não é de ninguém". ${ }^{4}$

Não há consenso entre os estudiosos no tocante à existência ou inexistência da propriedade em toda a história da sociedade humana. E uma das preocupações colocadas é no sentido de saber se a propriedade é um direito natural ${ }^{5}$ ou um fenômeno

\footnotetext{
${ }^{3}$ CAPELLA, Juan Ramón. Fruto Proibido: Uma aproximação histórico-teórica ao estudo do direito e do estado. Tradução: Gresiela Nunes da Rosa [et al]. Porto Seguro: Livraria do advogado, 2002.

${ }^{4}$ ROUSSEAU, Jean Jacques. Discurso sobre a origem e fundamentos da desigualdade ente os homens. , $2^{\mathrm{a}}$ ed., Portugal: Publicações Europa América, p. 53.

${ }^{5}$ Conforme lição de Roberto Lyra Filho, "O direito natural apresenta-se, fundamentalmente, sob três formas, todas elas procurando estabelecer o padrão jurídico, destinado a validar as normas eventualmente
} 
humano, tendo sido intenso o debate, principalmente, entre jusnaturalistas e positivistas ${ }^{6}$. Aqueles que consideram a propriedade como um direito ligado à própria criação, vale dizer, como direito natural, buscam justificar suas idéias nos mandamentos pregados nas escrituras sagradas. Exemplo: "não roubarás" e "não cobiçarás as coisas alheias". Deduzse daí que não há dúvidas quanto ao direito de propriedade, haja vista que, sendo o homem uma criatura de Deus, este concedeu àquele tudo que precisava para sobreviver, inclusive a propriedade. Logo, trata-se de um direito natural, não tendo nenhuma relação de natureza contratual. ${ }^{7}$

Essa tese da propriedade como direito natural ligado à obra do Criador não é aceita, conforme sustenta Marcelo Dias Varella:

\begin{abstract}
Ainda que sob uma análise teológica (...), desconsiderando Gêneses como um livro simbólico, Adão não tinha propriedades, mas vivia no paraíso, em harmonia com o todo e com seu Criador. Adão vivia no Jardim do Éden e Deus o 'tomou para cultivar e guardar' (Gen. 2,15), não havia qualquer noção de propriedade. Para que Adão não ficasse só e para satisfazer a seus desejos, Deus criou Eva e então nasce a primeira sociedade. Com o pecado capital, ambos são expulsos do paraíso, e, somente com seus filhos e com os filhos de seus filhos nasce a concepção da propriedade, criação humana e não divina, uma vez que não preexistente. ${ }^{8}$
\end{abstract}

No entendimento de Varella, a propriedade enquanto direito natural deve ser estudada tendo em mente não apenas o mundo greco-romano, mas toda a humanidade, “incluindo as civilizações orientais, ameríndias e mesmo do norte europeu, onde se percebe que o conceito de propriedade individual não existia, pois havia apenas uma noção de limite territorial, onde determinada tribo ou povo produzia seus alimentos, em harmonia com o meio ambiente e com seus deuses, mas não a propriedade em si”. ${ }^{9}$ Esse entendimento é confirmado com a análise feita por Fustel de Coulanges sobre o tema, na

produzidas, ou explicar por que elas não são válidas. As três formas são: a) o direito natural cosmológico; b) o direito natural teológico; c) o direito natural antropológico. A primeira liga-se ao cosmo, o universo físico; a segunda volta-se para Deus; a terceira gira em torno do homem" LYRA FILHO, Roberto. O quer é direito. São Paulo: Brasiliense, 1999.

${ }^{6}$ VARELLA, Marcelo Dias. Introdução ao direito à reforma agrária: o direito face aos novos conflitos sociais. Leme SP: LED - Editora de Direito Ltda, 1998, p. 191 e 194.

Para Lyra filho essa dicotomia que demarca os dois campos do direito entre jusnaturalistas e positivistas faz parte do discurso ideológico. Nesse sentido, é possível dizer que o jusnaturalismo e o positivismo jurídico são faces da mesma moeda. Afirma o autor que "a burguesia chegou ao poder desfraldando a bandeira ideológica do direito natural - com fundamento acima das leis - e, tendo conquistado o que pretendia, trocou de doutrina, passando a defender o positivismo jurídico (em substância, a ideologia da ordem assente)." LYRA FILHO, Roberto. O que é direito. São Paulo: Brasiliense, 1999, p. 23.

${ }^{7}$ VARELLA, Marcelo Dias. Introdução ao direito à reforma agrária: o direito face aos novos conflitos sociais. Leme SP: LED - Editora de Direito Ltda, 1998, p. 194-195.

${ }^{8}$ VARELLA, op. Cit, p. 195.

9 VARELLA, op. Cit. p. 195-196. 
medida em que, para este autor, existem raças que nunca tiveram propriedade, ao mesmo tempo em que menciona que entre os germanos a terra não pertencia a ninguém, havendo apenas direito de uso em sistema de rotação. A propriedade era apenas da colheita, situação que é comum na maioria dos povos, exceto entre os gregos, cuja situação se inverte, sendo a colheita comum, ao passo que a propriedade é privada. ${ }^{10}$ Já na Grécia e na Itália, segundo Fustel de Coulanges, sempre houve propriedade privada. ${ }^{11}$

Para o mencionado autor, "Há três coisas que, desde os tempos mais antigos, se encontram fundadas e estabelecidas solidamente pelas sociedades gregas e itálicas: a religião doméstica, a família e o direito de propriedade". ${ }^{12}$ Essa propriedade, no entanto, é ligada à religião, numa relação, inclusive, de respeito aos mortos que eram enterrados nas terras pertencentes à família ${ }^{13}$ e que iam sendo transmitidas automaticamente com a morte. ${ }^{14}$ A religião, portanto, é vista como forma exclusiva de adquirir propriedade na maior parte dos povos primitivos, numa relação totalmente diferente do modelo introduzido pelo Estado Moderno, conforme analisaremos adiante. Na verdade, conforme Fustel de Coulanges, "não foram as leis, mas a religião, aquilo que primitivamente garantiu o direito de propriedade". ${ }^{15}$

Feitas estas breves considerações históricas, ${ }^{16}$ entendemos oportuno estabelecer o diferencial que marca um divisor de águas entre o direito de propriedade antes e pós Estado Moderno, tratando-se de modelos totalmente diferentes.

Mesmo na Idade Média, com o controle do senhor feudal sobre a propriedade, existiam áreas coletivas destinadas ao uso comum para a caça e a pesca. ${ }^{17}$ A noção de

\footnotetext{
${ }^{10}$ FUSTEL DE COULANGES, Numa Denis (1830-1889). A cidade antiga. Tradução de Fernando de Aguiar. $4^{\text {a }}$ ed. São Paulo: Martins Fontes, 1998, p. 56-69.

${ }^{11}$ Op. cit., p. 57.

12 Op. cit., p. 58.

${ }^{13}$ A relação da propriedade com a família como condição de existência está presente no pensamento de Aristóteles, apesar do paradoxo do seu discurso, quando inclui os escravos no bojo do patrimônio familiar. Nesse sentido afirma Aristóteles que "A propriedade é parte de uma família e a aquisição de uma propriedade parte da arte de dirigir uma família; pois nenhum homem pode viver bem, ou mesmo viver, a menos que atenda às próprias necessidades" ARISTÓTELES, A política. São Paulo: Editora Nova Cultural Ltda, 1999, p. 148.

${ }^{14}$ Um estudo cuidadoso das origens da propriedade ligada à religião, nessa forte ligação com o lar, com a família e com os antepassados, pode ajudar a compreender os conflitos agrários, principalmente no que diz respeito à questão indígena e aos remanescentes de quilombos. No caso dos indígenas podemos citar como exemplo os Pataxós na Costa do Descobrimento, Região Sul do Estado da Bahia. Um dos argumentos que utilizam atualmente para a incorporação de determinadas áreas de terra na reserva indígena é o fato de haver antepassados seus enterrados naquelas áreas.

${ }^{15}$ FUSTEL DE COULANGES, 1998, p. 64.

${ }^{16}$ Não é objetivo desta primeira parte realizar estudo pormenorizado da história da propriedade antiga, mas apenas mencionar os principais aspectos diferenciadores da moderna concepção de propriedade em contraposição ao modo de vida anterior.

${ }^{17}$ VARELLA, 1998, p. 196.
} 
propriedade coletiva também é notada desde a Antiguidade nas comunidades gentílicas, a exemplo do Egito, Síria, Mesopotâmia e em outras regiões da Ásia, não pertencendo a terra a um indivíduo, mas sim a uma coletividade, aldeia ou comunidade. ${ }^{18}$

\section{A PROPRIEDADE MODERNA}

Com o pensamento liberal burguês, ocorre uma mudança radical do significado da propriedade, ${ }^{19}$ uma vez que esta passa a ser considerada como utilidade econômica. ${ }^{20} \mathrm{Na}$ abordagem de Miguel T. Pressburger, “com o advento e a disseminação da mercadoria na sociedade, as relações sociais são profundamente modificadas. $O$ mundo aparece diante dos homens como se fosse povoado de mercadorias que lhe são necessárias (valor de uso) e que eles se vêem obrigados a comprar (valor de troca) no mercado". 21

Neste contexto, a propriedade passa a ser um direito natural de caráter absoluto, sagrado, introduzido no ordenamento jurídico a partir da Revolução Francesa, posteriormente sistematizada no Código Napoleão, ${ }^{22}$ passando a constituir um dos pilares do direito privado. Como afirma Fachin,

Três pilares fundamentais, em cujos vértices se assenta a estrutura do sistema privado clássico, encontram-se na alça dessa mira: o contrato, como expressão mais acabada da suposta autonomia da vontade; a família, como organização social essencial à base do sistema, e os modos de apropriação, nomeadamente a posse e a propriedade, como títulos explicativos da relação entre as pessoas e sobre as coisas. (...). Privar, possuir e pertencer. A segurança desse sistema outorga um título a um sujeito sobre um objeto. Por aí se vê que ao menos dois séculos estacionados completam o indivíduo-centrismo, apto a captar um individualismo do século XVIII que atuou no regime civilista. ${ }^{23}$

\footnotetext{
18 VARELLA, 1998, p. 196.

19 “A propriedade (...) não consistia naquele poder ilimitado sobre as coisas que caracteriza nossas concepções individualistas de posse desde o início do século XIX” (HESPANHA, Antônio Manuel. O direito e a imaginação antropológica nos primórdios da era moderna. In: Novos estudos CEBRAP, n. 59, março de 2001, p. 137-152.

20 COMPARATO, Fabio Konder. Direitos e deveres fundamentais em matéria de propriedade. In: STROZAKE, Juvelino José (org.). A questão agrária e a justiça. São Paulo: Revista dos Tribunais, 2000, p. 130-147; MARÉS, Carlos Frederico. A função social da terra. Porto Alegre: Sergio Antônio Fabris Editor, 2003, p. 26.

${ }^{21}$ PRESSBURGER, T. Miguel. Terra, propriedade, reforma agrária e outras velharias. In: VARELLA, Marcelo Dias (org.). Revoluções no campo jurídico. Joinville: Oficina de Comunicações Editora, 1998, p. 298.

22 VARELLA, 1998: 197.

${ }^{23}$ FACHIN, Luis Edson. Teoria crítica do direito civil. Rio de Janeiro: Renovar, 2003, p. 13; FACHIN, Luis Edson. "Virada de Copérnico": um convite à reflexão sobre o direito civil brasileiro contemporâneo. In: FACHIN, Luis Edson (org.). Repensando os fundamentos do direito civil brasileiro contemporâneo. Rio de Janeiro: Renovar, 1998, p. 317-329; e FACHIN, Luis Edson. A reforma no direito brasileiro: novas
} 
Na mesma linha é o ensinamento de Warat, ao afirmar que "O capitalismo, para acomodar os indivíduos em seu proveito, impõe modelos de desejo. Assim circulam modelos de infância, de pai, de casamento, todos construídos em nome do dever de verdade. Dessa forma, no centro do desejo, fica instalada a propriedade."24

É na Revolução Francesa, portanto, que encontramos o marco jurídico da propriedade, tendo a Constituição o papel de organizar o Estado e garantir o direito, numa concepção marcada pelo monismo jurídico, vale dizer, só há um direito, o estatal, um direito universal e geral, tendo o Estado Moderno como finalidade precípua garantir a igualdade, a liberdade e a propriedade, com a prevalência desta última. Consoante lição de Marés, "Dito de outra forma, a função do Estado, no momento de sua constituição, era garantir a propriedade que necessitava da liberdade e igualdade para existir. Só homens livres podem ser proprietários, podem adquirir propriedade, porque faz parte da idéia da propriedade a possibilidade de adquiri-la e transferi-la livremente". ${ }^{25}$

Thompson, analisando o contexto da Inglaterra do século XVIII, marcada por intensos conflitos sociais, afirma que: "O Estado britânico, concordavam todos os legisladores do século 18, existia para preservar a propriedade e, incidentalmente, as vidas e liberdades dos proprietários". ${ }^{26}$ A proteção da propriedade passa a ser tarefa fundamental do Judiciário.

Um olhar sobre o mundo à época da consolidação do mencionado poder, enquanto um dos pilares do Estado Moderno, nos conduz à percepção de que o período foi marcado por uma gigantesca transformação, com o fim do feudalismo e a introdução do capitalismo como modo de produção predominante, ${ }^{27}$ que teve início com o mercantilismo e posteriormente com a revolução industrial. Na Inglaterra, os camponeses pobres são expulsos do campo onde exerciam posse sobre as terras para ceder lugar ao latifúndio necessário à ovinocultura extensiva para produção da lã, através do episódio que ficou conhecido como cercamentos ${ }^{28}$.

Em um movimento de ruptura, aos poucos, os camponeses europeus se viram obrigados a habitar as cidades que se formavam, tendo a maioria passado a sobreviver em

notas sobre um velho debate no direito civil. In: Noticia do direito brasileiro. Nova série, n. 10. Universidade de Brasília, Faculdade de Direito, 2004, p. 61-68.

${ }^{24}$ WARAT, Luis Alberto. A ciência jurídica e seus dois maridos. $2^{\mathrm{a}}$ ed. - Santa Cruz do Sul: EDUNISC, 2000 , p. 38.

${ }^{25}$ MARÉS, 2003: 18.

26 THOMPSON, 1924: 21.

${ }^{27}$ PRESSBURGER, 1998: 297-310.

${ }^{28}$ MARÉS, 2003, p. 26. 
condições subumanas. Enquanto isso, aqueles que se constituíram como classe economicamente privilegiada da época, os burgueses, necessitavam de um artifício que lhes permitisse ao mesmo tempo estar na terra, mesmo morando na cidade e exercendo a atividade industrial e comercial, conforme nos ensina Miguel Lanzellotti Baldez, ao introduzir a discussão dos conflitos de terra no campo a partir da distinção entre posse e propriedade, sendo a primeira, vale dizer, a posse, uma relação de fato entre o homem e a terra, ao passo que a propriedade se estabelece por uma relação jurídica. ${ }^{29}$

Conforme explica Baldez,

\begin{abstract}
...na transição, no Ocidente, do modo de produção feudal para o modo de produção capitalista, com a transferência da estrutura econômica da sociedade do campo para a cidade, era fundamental para a classe que se qualificaria como dominante garantir a titulação sobre o monopólio da terra. Enquanto a essência da produção estava no campo, enquanto não se tinha ainda caracterizado a cidade como espaço produtivo, não se teve preocupação de distinguir com clareza entre posse e propriedade. Essa necessidade só foi aparecer naquele momento de transição, pois como se disse acima, os que haviam acumulado a riqueza precisavam encontrar, saindo do campo para a cidade, o meio adequado de ficar na terra sem estar fisicamente nela. Somente um artifício jurídico seria capaz de assegurar esse resultado: o vínculo - mera abstração jurídica da propriedade. ${ }^{30}$
\end{abstract}

\title{
4 A FILOSOFIA POLÍTICA LIBERAL DA PROPRIEDADE PRIVADA
}

Passamos agora à análise dos fundamentos político-filosóficos e jurídicos da propriedade, cuja influência é marcante na atuação do judiciário, tendo a filosofia política do inglês John Locke como principal representante do pensamento liberal sobre o tema, sem perder de vista que o século XIX marca apenas o coroamento de uma ideologia da propriedade que já vinha sendo delineada três séculos antes. Nota-se, no período, uma forte influência da Igreja nesse debate, uma vez que muitos desses teóricos eram bispos, padres e pastores, tendo o pensamento religioso católico e protestante deixado sua marca no debate sobre a propriedade. ${ }^{31}$

Não significa, contudo, que na Igreja tenham sempre prevalecido as mesmas idéias. Ao contrário, o que percebemos é um certo comportamento pendular e

\footnotetext{
${ }^{29}$ BALDEZ, Miguel Lanzellotti. A terra no campo: a questão agrária. In: MOLINA, Mônica Castagna, SOUSA JÚNIOR, José Geraldo e TOURINHO NETO, Fernando da Costa (org.). Introdução crítica ao direito agrário. Série o direito achado na rua, v. 3, Brasília: Editora UNB, 2002, p. 95-106.

${ }^{30}$ BALDEZ, 2002: 97.

${ }^{31}$ MARÉS, 2003: 19.
} 
heterogêneo nesta matéria, vale dizer, nem todos estavam de acordo com o modelo que foi consolidando a relação do homem com a natureza, tendo em teóricos da Igreja como São Basílio, que denuncia a avareza, a acumulação desnecessária, exemplo de postura diferenciada. ${ }^{32}$ No mesmo sentido, comporta-se Santo Tomás de Aquino que, mesmo admitindo a existência da propriedade, não aceita a idéia de um direito natural, absoluto e excludente, oponível contra todos, mas sim como valor de uso para o bem comum. Em Santo Tomás de Aquino, a idéia de disposição das coisas não significa a comercialização, mas, sim, a transferência para os necessitados. ${ }^{33}$

No século XVIII, com o advento das teorias políticas que introduzem o discurso da propriedade privada como valor de troca, a Igreja passa a ter um outro comportamento acerca do tema, inicialmente "abençoando" a propriedade feudal e, posteriormente, a mercantil. ${ }^{34}$ Como assegura Marés, "Mesmo quando a Igreja Católica começou a construir uma posição crítica ao liberalismo, com a encíclica Rerum Novarum (1891), o fez em defesa da propriedade privada contra o socialismo que propunha a sua abolição". ${ }^{35}$ Com efeito, o Papa Leão XIII, na encíclica Rerum Novarum, sustenta a idéia da propriedade privada como direito natural embasando-se na racionalidade e no sentido do trabalho humano. ${ }^{36}$

Só mais recentemente a Igreja volta a tomar posições que vinculam a propriedade a uma idéia de justiça social. Nesse sentido foi encaminhado o discurso do Papa João Paulo II no Concílio de Puebla, em 1979, ao pontificar que "sobre toda propriedade pesa uma hipoteca social." ${ }^{\prime 37}$

Em matéria de direito civil, vamos encontrar na Alemanha, em Rudolfo Von Ihering, a teoria que ainda hoje, já sob as luzes do século XXI, influencia a formação e a prática de grande parte dos operadores do direito no Brasil. Importa esclarecer desde logo que a teoria jurídica de Ihering encontra-se totalmente ultrapassada, não tendo mais respaldo nem mesmo entre os dogmáticos do direito mais atualizados. Na verdade, atualmente, conforme assinala Marés, "é visível a crise deste modelo, o Estado e a

\footnotetext{
${ }^{32}$ MARÉS, 2003: 20.

${ }^{33}$ MARÉS, 2003: 21-22.

${ }^{34}$ MARÉS, 2003: 22.

${ }^{35}$ Op. cit.: 22.

${ }^{36}$ SANTOS, Fábio Alves dos. Direito agrário: política fundiária no Brasil. Belo Horizonte: Del Rey, 1995, p. 168.

${ }^{37}$ MARÉS, 2003, p. 22
} 
propriedade, assim concebidos e realizados, chegaram a seu esgotamento teórico e prático". ${ }^{38}$

Era necessária, todavia, uma justificativa filosófica para essas transformações. O grande filósofo representante do pensamento liberal burguês do período, conforme já mencionado, é John Locke. Esse filósofo, na obra denominada Dois Tratados Sobre o Governo ${ }^{39}$, lança as bases do pensamento liberal acerca do direito de propriedade, tendo na idéia do trabalho o fio condutor do seu discurso.

Locke olha para o universo comparando-o a uma grande obra, sendo Deus "um artífice, um obreiro, arquiteto e engenheiro que fez uma obra, o mundo", ${ }^{40}$ e, na qualidade de único proprietário, concede aos homens em comum para a sua sobrevivência. Nessa perspectiva nenhum homem pode ser proprietário da terra. É o que podemos observar das palavras do mencionado filósofo: "Quer consideremos a razão natural - que nos diz que os homens, uma vez nascidos, têm direito à sua preservação e, portanto, à comida, bebida e tudo quanto a natureza lhes fornece para sua subsistência ou a revelação - que nos relata as concessões que Deus fez do mundo para Adão, Noé e seus filhos -, é perfeitamente claro que Deus, como diz o Rei Davi (SI 115, 61), deu a terra aos filhos dos homens, deu-a para a humanidade em comum". ${ }^{41}$

Essa constatação serve apenas como ponto de partida para Locke tentar encontrar argumentos que possibilitassem aos homens se transformarem em proprietários da terra. Segue, portanto, o filósofo: “(...) Contudo, esforçar-me-ei por mostrar de que maneira os homens podem vir a ter uma propriedade em diversas partes daquilo que Deus deu em comum à humanidade, e isso sem nenhum pacto expresso por parte de todos os membros da comunidade". ${ }^{42}$ Nota-se que Locke inicia seu discurso afastando a idéia do contrato, não admitindo a possibilidade de apropriação da terra como objeto de compra e venda, mas sim como uso, como utilidade, estando, nesse sentido, de acordo com o pensamento de Santo Tomás de Aquino.

É também na ideia do homem enquanto ser racional que Locke vai encontrar o seu ponto de partida para justificar a apropriação da terra. Na concepção de Locke os homens receberam do ser supremo não só o mundo, mas também a razão. Dotado de

\footnotetext{
${ }^{38}$ MARÉS, 2003, p. 18

39 LOCKE, John. Da propriedade. In: LOCKE John. Dois tratados sobre o governo. Tradução Julio Fischer. São Paulo: Martins Fontes, 1998, p. 405-429.

${ }^{40}$ CHAUÍ, Marilena. Convite à filosofia. São Paulo: Ática, 1997.

${ }^{41}$ LOCKE, op. Cit, p. 406

${ }^{42}$ LOCKE, op. Cit. P. 406
} 
razão, um homem que age, não por instinto, mas por consciência, pode usar a natureza na perspectiva de uma vida melhor. ${ }^{43}$

Para mostrar a importância do trabalho enquanto fonte de bens apropriáveis, Locke refere-se à propriedade do próprio corpo que cada indivíduo tem, ou seja, quando Deus concedeu a Terra e todas as coisas inferiores aos homens de forma comum não foi retirado do indivíduo a propriedade sobre o próprio corpo. Sendo o homem proprietário do próprio corpo, a transformação que faz das coisas da natureza, que no estado natural pertencem a todos em comum, passa agora a pertencer àquele que através do seu trabalho conseguiu transformar a natureza, acrescentando algo a ela. ${ }^{44}$

Através do trabalho, o homem transforma a natureza criando novos frutos distintos daqueles encontrados em seu estado natural. O produto do trabalho, portanto, passa a ser propriedade privada. "Vemos nas terras comuns, que assim permanecem em virtude de um pacto, que é o tomar qualquer parte daquilo que é comum e retirá-la do estado em que a deixa a natureza que dá início à propriedade; sem isso, o comum não tem utilidade alguma. (...) O trabalho que tive em retirar essas coisas do estado comum em que estavam fixou a minha propriedade sobre elas". ${ }^{45}$

A terra continua comum, sendo a possibilidade de apropriação, até então, apenas sobre as coisas nela encontradas, exemplificando com a apropriação do cervo abatido pelo índio, da mesma forma todos os bens, mesmo que fossem comuns, passaram a pertencer àquele que dedicou trabalho. ${ }^{46}$

Essa apropriação, na concepção de Locke, não é de forma indiscriminada, conforme afirmamos antes. Nota-se que há um limite. Este limite é o uso, a fruição, não a acumulação. Assim, diz o autor: “A mesma lei da natureza que por este meio nos concede a propriedade, também limita essa propriedade. Deus deu-nos de tudo em abundância $(1 \mathrm{Tm} 6,17)$ é a voz da razão confirmada pela revelação. Mas até que ponto ele no-lo deu? Para usufruirmos". ${ }^{47}$ (op. cit.: 412).

Apesar de Locke, no seu ponto de partida, entender que a terra é comum a todos, sendo proprietário apenas o Ser Supremo, com o discurso do trabalho que possibilita a apropriação das coisas encontradas sobre a terra e transformadas, agora o filósofo passa a entender que mesmo a porção de terra arada e cultivada e o produto

\footnotetext{
${ }^{43}$ LOCKE, op. Cit. P. 407

${ }^{44}$ LOCKE, op. Cit. P. 407-409; 423-424

${ }^{45}$ LOCKE, op. Cit, p. 410

${ }^{46}$ LOCKE, op. Cit, p. 411.

${ }^{47}$ LOCKE, op. Cit, p. 412.
} 
decorrente desse trabalho podem constituir propriedade privada. Dessa forma, aquilo que antes era bem comum, através do trabalho pode ser apropriado individualmente. Volta o filósofo à origem para justificar nas palavras do "grande arquiteto" que, ao conceder o mundo a toda a humanidade, teria ordenado que todos trabalhassem. Assim, é a razão divina que ordena o homem a dominar a terra, transformando a natureza, através do trabalho, para criar condições de vida. "Aquele que, em obediência a essa ordem de Deus, dominou, arou e semeou qualquer parte dela, acrescentou com isso algo que era de sua propriedade, ao que os demais não tinham qualquer título, nem podiam tomar-lhe sem causar-lhe injúria". ${ }^{48}$

$\mathrm{Na}$ argumentação de Locke, o fato de Deus haver dado o mundo aos homens em comum não significa que essa comunhão tenha se transformado em um decreto para toda a eternidade, haja vista que, como já afirmado anteriormente, a concessão do mundo aos homens foi feita no sentido de possibilitar os maiores benefícios possíveis. ${ }^{49}$

A ideia de aquisição de propriedade através do trabalho, no pensamento de Locke, não significava, a princípio, a acumulação. Ao contrário, entendia o filósofo que seria impossível através do trabalho acumular propriedade para além do necessário ao conforto humano, não sendo justificável a usurpação dos direitos dos outros. ${ }^{50}$ Esse argumento é justificado também na constatação da existência de terra em abundância, uma vez que há espaço para todos. Para Locke, a acumulação só foi possível com a invenção do dinheiro e o pacto entre os homens no sentido de possibilitar a aquisição de posses através desse instrumento. ${ }^{51}$

É possível notar que a aquisição de propriedade, que na fundamentação inicial de Locke é feita através do trabalho, passa agora a ser permitida através do dinheiro, sendo a terra transformada em mercadoria, em objeto de compra e venda, afastando aquela anterior relação de uso, de utilidade.

Nota-se no discurso de Locke sobre a propriedade uma análise comparativa entre o agricultor da Europa e o indígena da América, do ponto de vista do valor de mercado das coisas produzidas na terra, sempre tendo em vista a quantidade de trabalho empregado. Argumenta que certa quantidade de terra cultivada na Europa por um trabalhador tem o mesmo valor intrínseco da mesma quantidade cultivada por um

\footnotetext{
${ }^{48}$ LOCKE, op. Cit, p. 412-413.

${ }^{49}$ LOCKE, op. Cit, p. 414.

${ }^{50}$ LOCKE, op. Cit, p. 415.

${ }^{51}$ LOCKE, op. Cit, p. 416-417
} 
indígena da América, todavia a diferença é percebida nos benefícios econômicos que podem obter, justificando, mais uma vez, a importância do trabalho como algo que introduz a maior parte do valor à terra. ${ }^{52}$

Um outro aspecto que entendemos relevante na análise do discurso de Locke diz respeito à diferença que ele faz entre as coisas deterioráveis ou de curta duração e aquelas que não o são. ${ }^{53}$ Essa diferença é fundamental na configuração do direito de propriedade capitalista, na medida em que, na argumentação do filósofo, não é admissível a acumulação das coisas deterioráveis colhidas na natureza, sendo permitida apenas a apropriação daquilo que de fato pode ser consumido. Não admite o desperdício, diferentemente da ética capitalista que, embasa na lei da oferta e da procura, justifica tal fato. ${ }^{54}$ Para o filósofo, tudo que exceder ao necessário é considerado como apropriação ilegítima da parcela comum. Todavia, às coisas de longa duração, como o ouro, a prata, o diamante, foi atribuído um outro valor que está para além do mero sustento. ${ }^{55}$

Com esse discurso, Locke passa a admitir a acumulação, uma vez que só não a admite no tocante às coisas de curta duração. Dessa forma, ao convencionar que o ouro, a prata e o diamante são coisas duráveis e tendo sido atribuído a essas coisas um valor de troca, alguns homens passam a acumular esses metais que podem ser trocados por outras coisas duráveis, incluindo nesta categoria a terra. "Onde não há nada que seja ao mesmo tempo escasso e durável, e tão valioso que possa ser acumulado, os homens não são capazes de aumentar as suas posses de terra, por mais ricas que estas sejam ou por maior liberdade que tenham para tomá-las." 56

O discurso de Locke é paradoxal, uma vez que, ao mesmo tempo em que admite a acumulação, a partir do discurso da aquisição do título de propriedade pelo trabalho, traz a idéia do limite. Vejamos o que diz o filósofo: "Desse modo, penso eu, tornar-se muito fácil conceber sem a menor dificuldade de que modo pôde o trabalho, no princípio, dar inicio a um título de propriedade sobre as coisas comuns da natureza, e de que modo o gasto das mesmas para o nosso uso limitava essa propriedade. ${ }^{57}$

\footnotetext{
52 LOCKE, op. Cit. P. 423

${ }^{53}$ Marés usa o termo bens corruptíveis. Segundo o mencionado autor, "esta lógica é o ponto chave para constituir a legitimidade da acumulação capitalista futura, porque restringia o bem comum às coisas corruptíveis, como os alimentos" (op. cit. p. 25).

${ }^{54}$ MARÉS, op. cit, p. 25.

55 LOCKE, op. Cit, p. 425-426. Como afirma Marés, "Locke em sua construção teórica justifica a acumulação capitalista, reconhecendo que a propriedade pode ser legítima e ilimitada se se transforma em capital, em ouro, em prata, em dinheiro" (op. cit., p. 24)

${ }^{56}$ LOCKE, op. Cit, p. 427

${ }^{57}$ LOCKE, op. Cit, p. 429
} 
No mesmo sentido dessa relação entre a aquisição e acumulação das coisas da natureza pelo trabalho, Voltaire, por seu turno, vincula a propriedade à liberdade. ${ }^{58}$ Sendo assim, só é livre quem é proprietário. Dizendo de outro modo, só pode ser proprietário quem é livre. Nesse caso, o escravo, evidentemente, não pode ser proprietário, apesar de trabalhar e o seu trabalho ser fonte de riqueza.

Essa relação da propriedade com a liberdade é apontada por Marés como a contradição da terra, na medida em que "a propriedade feudal, relativa e ligada a servos não-proprietários se contrapunha à outra propriedade nascente, de homens livres, que livremente contratavam sua força de trabalho, para proprietários absolutos, que determinavam o que, como e quando plantar". 59

É a partir dessa concepção da propriedade ligada ao trabalho que em Portugal é criada a primeira lei de terras, cuja influência na formação da cultura jurídica proprietária no Brasil é marcante, ${ }^{60}$ conforme analisaremos em outro lugar.

O êxodo rural decorrente da crise do feudalismo e das transformações introduzidas pelo novo modo de produção nascente, ao mesmo tempo em que gera uma série de contradições, com um grande movimento migratório em Portugal, gera também a necessidade de ocupação e cultivo das terras. Essa nova realidade marcada por sérios problemas sociais conduz à criação não só de inúmeras legislações para regular a locação de trabalho, mas também leis para punir a vadiagem. Entretanto, essa proliferação legislativa não é suficiente para dar conta dos problemas decorrentes da aglomeração de pessoas nos centros urbanos, fato que conduz o Estado Português à criação de legislação para regulamentar o acesso à terra. É nesse novo contexto que é criada em Portugal a primeira lei de terras, denominada lei de sesmarias ${ }^{61}$ que regula o acesso e uso da terra a partir de uma concepção de cultivo, de utilização da terra, não permitindo, assim, a acumulação pura e simplesmente. ${ }^{62}$

A pessoa ou família que recebia determinada faixa de terra, por um prazo que era de cinco anos, tinha a obrigação de cultivar, sob pena de ser retomada e repassada a

\footnotetext{
${ }^{58}$ MARÉS, op. cit., p. 27.

${ }^{59}$ MARÉS, op. cit., p. 27.

${ }^{60}$ MARÉS, op. cit., p. 28.

${ }^{61}$ Conforme disposto nas Ordenações Filipinas, "Sesmarias são propriamente dadas de terras, casas ou pardieiros, que foram ou são de algum senhorio, e que já em outro tempo foram lavradas e aproveitadas, e agora o não são. As quais terras e os bens assim danificados e destruídos podem e devem ser dados em sesmarias pelos Sesmeiros, que para isso forem ordenados" (MARÉS, op. cit., p. 31). Essa legislação das sesmarias serviu para criar o latifúndio no Brasil, ao contrário do que ocorreu na metrópole, cuja utilização serviu para distribuir a terra.

${ }^{62}$ MARÉS, op. cit., p. 29.
} 
outrem. Na hipótese de cumprimento do estipulado, adquiria o direito à gleba. Com o passar do tempo, o instituto deixou der ser utilizado em Portugal, perdendo força a idéia de uso, passando a prevalecer o modelo de propriedade como garantia e exclusividade, modelo este que servirá de base para o Estado constitucional do Século XIX e será transportado para as colônias. ${ }^{63}$

Como afirma Marés, "a propriedade mercantil portuguesa nasceu como um direito ao uso produtivo, mas foi se transformando até ser um direito independente, cuja legitimidade estaria vinculada ao negócio jurídico que a trocou por dinheiro ou outro bem não corruptível. Comparando assim a trajetória da teoria com a prática portuguesa fica fácil entender o processo histórico de criação da propriedade privada no mundo contemporâneo e a afirmação certa de que ela é uma invenção recente, construção humana que nada tem de sagrada, nem de natural". ${ }^{64}$

A nova concepção de propriedade, fundamentada na idéia do trabalho, consolidada no século XIX, e que tem no braço judiciário do governo civil seu garantidor, é uma concepção exclusivista e individualista que, a partir do mencionado período, passa a integrar as Constituições do Estado Moderno, sendo melhor esquematizada nos diplomas legais que regulamentam o direito privado, mais especificamente nos códigos civis. ${ }^{65}$

A Constituição francesa de 1793 , em seu artigo $1^{\circ}$, prevê que "O governo existe para garantir ao homem o gozo dos seus direitos naturais e imprescritíveis", sendo estes direitos previstos no artigo $2^{\circ}$, quais sejam: "a igualdade, a liberdade, a segurança e a propriedade". 66

No mesmo sentido é o previsto na Constituição espanhola de 1812, enfatizando a primazia do direito de propriedade ao prever que "A nação tem o dever de conservar e proteger, por meio de leis sábias e justas, a liberdade civil, a propriedade e os demais direitos legítimos de todos os indivíduos que a compõem". ${ }^{67}$

No mesmo período (1822), a primeira Constituição portuguesa garante o direito de propriedade nos seguintes termos: "a Constituição Política da Nação Portuguesa tem por objeto manter a liberdade, segurança e propriedade de todos os

\footnotetext{
${ }^{63}$ MARÉS, op. cit. 31.

${ }^{64}$ MARÉS, op. cit., p. 32.

${ }^{65}$ MARÉS, op. cit., p. 32-34

${ }^{66}$ MARÉS, op. Cit., p. 33.

${ }^{67}$ MARÉS, op. Cit. 33
} 
portugueses", dispondo ainda, no seu artigo $6^{\circ}$, que a propriedade é um direito sagrado e inviolável de se dispor à vontade de todos os bens. ${ }^{68}$

No Brasil, quando ainda vigorava o regime de escravidão, mesmo prevendo a desapropriação, a Constituição imperial de 1824 segue a mesma direção, ao prever que a inviolabilidade dos direitos civis e políticos dos cidadãos brasileiros, que tem por base a liberdade, a segurança individual e a propriedade, é garantida pela Constituição do Império, fazendo-o através da garantia do direito de propriedade em toda sua plenitude, assegurando aos proprietários o direito à indenização prévia. (art. 179, XX). ${ }^{69}$

Em 1916, é promulgado no Brasil o Código Civil (Lei 3.071, de $1^{\circ}$ de janeiro de 1916), que vigorou até 10 de janeiro de 2003, sendo parcialmente modificado pela Lei n. 10.406, de 10 de janeiro de 2002, que instituiu o denominado Novo Código Civil. No código de 1916, as regras sobre a propriedade retratam fielmente a concepção consolidada no século XIX, garantindo ao proprietário, no artigo 524, o direito de usar, gozar e dispor de seus bens e de reavê-los do poder de quem quer que injustamente os possua. ${ }^{70}$ Essa é a regra resultante da concepção exclusivista do Estado Moderno que, no afã de garantir o direito de propriedade, assegura ao detentor desse direito a faculdade de excluir os outros e de devastar a natureza, numa evidente prevalência do individual sobre o coletivo.

Macpherson estuda o direito de propriedade em dois grandes períodos históricos. No primeiro período, que tem início em Aristóteles e vai até o Século XVII, o direito de propriedade se desdobra no direito de excluir outrem do uso e gozo e no direito individual de não ser excluído das coisas de uso comum. Já no segundo período, que tem início no século XVII e se estende aos tempos atuais, o autor observa um estreitamento da noção de propriedade, ficando o conceito reduzido ao direito de exclusão. ${ }^{71} \mathrm{O}$ individual, o privado, passa a constituir a regra e o público ou coletivo a exceção, não havendo lugar para a inclusão mas tão somente para a apropriação individual das coisas. Sendo assim, para que o Estado, em caso de necessidade ou utilidade pública, possa se apropriar de alguma fatia da propriedade privada, torna-se necessária a desapropriação. ${ }^{72}$ Essa concepção vai gerar seus efeitos no modelo de apropriação da terra no Brasil, conforme tivemos oportunidade de refletir em outro lugar.

\footnotetext{
${ }^{68}$ MARÉS, op. Cit., p. 33

${ }^{69}$ MARÉS, op. cit., p. 34.

${ }^{70}$ MARÉS, op. cit., p. 34.

${ }^{71}$ Apud MARÉS, op. cit., p. 37.

${ }^{72}$ MARÉS, op. cit., p. 33, 37339.
} 


\section{DAS RUPTURAS À INTRODUÇÃO DO CONCEITO DE FUNÇÃO SOCIAL DA PROPRIEDADE NAS CONSTITUIÇÕES MODERNAS}

O debate em torno dessa concepção liberal individualista da propriedade não se esgotou com o advento das Constituições Modernas e com o direito dos códigos. Ao contrário, diversos foram os teóricos que, no Século XIX, marcaram posição de questionamento à referida concepção. Para Proudhom, a propriedade é um roubo. Severas críticas no sentido de condenação à concepção liberal da propriedade também são encontradas em Marx e Engels. ${ }^{73}$ Em suas reflexões acerca da relação entre trabalho e propriedade privada, diz Marx: "O trabalhador se torna tanto mais pobre quanto mais riqueza produz, quanto mais a sua produção aumenta em poder e extensão. $O$ trabalhador se torna uma mercadoria tão mais barata quanto mais mercadorias cria."74

A doutrina social da Igreja Católica, mesmo defendendo a propriedade privada, conforme já afirmado anteriormente, critica a desumanidade da exclusividade da aquisição da propriedade através da liberdade de contratar. Tal crítica é feita pelo Papa Leão XIII, em 1891, ao publicar a encíclica Rerum Novarum . Como diz Marés, "Se a liberdade é a escolha entre muitos, só o patrão tinha a liberdade porque tinha à sua frente um batalhão de famintos pronto a ser contratado por qualquer preço que mitigasse a sua fome diária". ${ }^{75}$

O confronto das teorias que criticam a concepção exclusivista da propriedade pode ser melhor compreendido na seguinte passagem da obra de Marés:

O produto do trabalho do operário era seu, mas pelo contrato ficava transferido ao empregador, na idéia geradora de Locke. A única pergunta jurídica que cabia neste contexto era: 'quis fazê-lo?' e não 'teve necessidade de fazê-lo?' ou ainda 'pode escolher entre várias alternativas?' Estas perguntas foram respondidas por Marx e os socialistas e teve como conseqüência a deslegitimação da propriedade na sua origem. O Papa também se fez a mesma pergunta e respondeu na Encíclica Rerum Novarum que, para que possa ser garantida a propriedade privada é necessário que o contrato seja além de legítimo, justo, e para isso o Estado deve intervir. ${ }^{76}$

\footnotetext{
${ }^{73}$ MARÉS, op. cit., p. 35.

${ }^{74}$ MARX, Karl. Trabalho estranhado e propriedade privada. In: ANTUNES, Ricardo (org.). A dialética do trabalho. São Paulo: Expressão Popular, 2004, p. 176.

${ }^{75}$ MARÉS, op. cit., p, 40.

${ }^{76}$ Op. cit. p. 41.
} 
Assim, é possível perceber que, ao mesmo tempo em que se consolida a propriedade moderna com seu caráter exclusivista, fruto da visão capitalista, ${ }^{77}$ na segunda metade do Século XIX, vão se consolidando também duas posições acerca da legitimidade e da exclusividade do mencionado direito. De um lado, os socialistas que rejeitam o caráter individual da propriedade de bens essenciais, estando a terra incluída nesta categoria. Para essa concepção, a propriedade de tais bens é ilegítima. De outro lado, temos a concepção liderada pela Igreja, defendendo que a legitimidade não se vincula necessariamente à legalidade do contrato, buscando agregar ao direito de propriedade ideais de justiça. ${ }^{78}$ Por essa última doutrina, podemos dizer que nem tudo que é legal é justo. ${ }^{79}$ É necessário, portanto, que o contrato de trabalho, como algo gerador de propriedade na concepção de Locke, não apenas seja válido do pondo de vista legal no sentido estrito, mas que também seja justo, para garantir ao trabalhador vida digna e possibilidade de também adquirir propriedade. Em sinete, a Rerum Novarum pugnava pela limitação do direito de propriedade por intermédio da revisão da liberdade de contratar. $^{80}$

No mencionado período, o debate acerca da propriedade não se limitava às correntes teóricas. Ao contrário, as mudanças que viriam a ser introduzidas na concepção jamais seriam concretizadas não fossem as lutas perpetradas por trabalhadores nas mais diversas regiões do mundo. Nos países capitalistas industrializados teve importância a luta do movimento sindical por melhores condições de trabalho, ao mesmo tempo em que nas Américas outras lutas foram ganhando força, a exemplo da revolução agrária no México. No Brasil, eclodiram importantes movimentos de camponeses excluídos do acesso à terra, a exemplo de Canudos no Sertão da Bahia e Contestado em Santa Catarina. $^{81}$

\footnotetext{
${ }^{77}$ MARÉS, op. cit., p. 81.

${ }^{78}$ MARÉS, op. cit., p. 41-42 e 81-84.

${ }^{79}$ Sobre a concepção positivista, que vincula o justo ao legal, Roberto Lyra Filho cita João Mangabeira para criticar o tradicional adágio segundo o qual "Justiça é dá a cada um o que é seu" nos seguintes termos: "A propósito de "dar a cada um o que é seu", como princípio "jurídico", mostrava o grande jurista João Mangabeira que é expressão muito velha da separação social das classes entre os proprietários e nãoproprietários, entre os dominantes e os espoliados: "porque se a justiça consiste em dar a cada um o que é seu, dê-se ao pobre e a pobreza, ao miserável a miséria, ao desgraçado a desgraça, que é isso o que é deles... Nem era senão por isso que ao escravo se dava a escravidão, que era o seu, no sistema de produção em que aquela fórmula se criou. Mas bem sabeis que esta justiça monstruosa tudo pode ser, menos justiça. A regra da Justiça deve ser a cada um segundo o seu trabalho, como resulta da sentença de São Paulo na carta aos Tessalonicenses, enquanto não atinge o princípio de a cada um segundo a sua necessidade" LYRA FILHO, Roberto. O que é direito. São Paulo, Brasiliense, 1982, p. 21.

${ }^{80}$ MARÉS, op. cit., p. 82.

${ }^{81}$ MARÉS, op. cit., p. 82.
} 
As pressões advindas dos movimentos sociais na Europa conduziram os países industrializados a implementar mudanças que, mesmo não tendo significado profundas rupturas paradigmáticas, possibilitaram a implementação de um Estado de Bem Estar Social, com melhores condições de trabalho e de vida, consideradas as reduções da jornada de trabalho, melhores salários, abonos diversos e férias remuneradas, estabilidade e planos de previdência social e seguros contra acidentes, saúde, educação. Tais mudanças, no entanto, não seriam possíveis sem uma alteração da estrutura agrária. Assim é que, mesmo mantendo o direito de propriedade na concepção consolidada no Estado Moderno, os países capitalistas do centro, com o fim da Primeira Guerra Mundial, resolvem implementar uma distribuição da terra acompanhada de política de financiamento, possibilitando ao trabalhador, melhores condições de vida. ${ }^{82}$

Nessa nova conjuntura de intervenção na economia, a estrutura jurídica dos estados capitalistas europeus passa a sofrer mudanças significativas, com alcance no direito de propriedade, na medida em que tal direito perde aquele caráter exclusivista do período anterior, ${ }^{83}$ passando as constituições a não só permitir, mas sobretudo determinar a intervenção na propriedade privada, para a efetividade do Estado de Bem Estar Social. A referida intervenção, que tem início na Alemanha de Bismark, vai se concretizar com mais rigor em matéria de limitação do direito de propriedade na Constituição da Alemanha de Weimar, de 11 de agosto de 1919. A mencionada carta política determinava, em seu artigo 153, que "A propriedade obriga e o seu uso e exercício devem representar uma função no interesse social". Permitia inclusive, em casos autorizados por lei, desapropriação sem indenização. ${ }^{84}$

Nota-se que essas mudanças da estrutura agrária são implementadas apenas nos países centrais, permanecendo os países da semiperiferia e da periferia sem alterações

\footnotetext{
${ }^{82}$ MARÉS, op. cit., p. 84.

83 Dentre os juristas, León Duguit, professor de Direito Constitucional da Faculdade de Direito de Bordeaux, na França, inaugurou, em 1911, o combate ao caráter exclusivista da propriedade. Em palestra proferida na Faculdade de Buenos Aires, o mencionado autor defende a necessidade de uma mudança de concepção, devendo a propriedade perder a natureza de direito subjetivo individual, passando a ser uma função social. Para o mencionado jurista "Todo o indivíduo tem a obrigação de cumprir na sociedade, certa função, em razão direta do lugar que nela ocupa. Por conseguinte, o possuidor da riqueza, pelo fato de possuí-la, pode realizar certo trabalho que somente ele pode cumprir. Só ele pode aumentar a riqueza geral, assegurar a satisfação das necessidades gerais, ao fazer valer o capital que possui. Está, pois, obrigado socialmente a cumprir esta tarefa, e só no caso de que a cumpra, será socialmente protegido. A propriedade não é um direito subjetivo do proprietário. É a função social do possuidor da riqueza" (Apud VARELLA, Marcelo Dias. Introdução ao direito à reforma agrária:.o direito em face aos novos conflitos sociais. São Paulo: LED Editora de Direito, 1998, p. 206.

${ }^{84}$ MARÉS, op. cit., p. 84.
} 
profundas da estrutura agrária, sem que se cumprissem as promessas da modernidade. ${ }^{85}$ No caso dos primeiros, a exemplo de Portugal, o processo de reforma agrária é incompleto, fato que é determinante para que o mencionado País seja considerado semiperiférico, conforme nos ensina Pedro Hespanha, ao asseverar que:

\begin{abstract}
Em Portugal, diferentemente de outros países da Europa, a dissolução da grande propriedade e a sua transferência para os pequenos produtores foi tardia e incompleta e não beneficiou de um impulso decisivo do Estado através de políticas dirigidas a facilitar a transferência do fundiário, nomeadamente de políticas de crédito (predial e agrícola).

A história da penetração das relações capitalistas na agricultura portuguesa evidencia a extraordinária capacidade de sobrevivência do Antigo Regime e das relações fundiárias e instituições de tipo pré-capitalista.

(...) No princípio do século XIX, a grande maioria da população rural era constituída por produtores sem terra, cerca de $80 \%$ da população activa agrícola, segundo a fonte utilizada por Vitorino Magalhães Godinho. ${ }^{86}$
\end{abstract}

No caso dos países periféricos, como os da América Latina e África, permaneceu intocada a estrutura fundiária herdada do período colonial, cuja marca principal é o latifúndio monocultor, com uma agricultura voltada para a exportação. As conquistas sociais experimentadas nos países da América Latina são tímidas, uma vez que a dependência é a marca do projeto de Estado de Bem-Estar conduzidos por ditaduras, a exemplo do Brasil com Getúlio Vargas e da Argentina com Juan Domingos Perón. Nestes países, é muito grande o distanciamento entre a lei e sua efetividade em matéria de direitos sociais. No caso da propriedade da terra no Brasil, permanece sem alteração do caráter exclusivista do direito de propriedade nos mesmos moldes estabelecidos no século XIX, excetuada apenas a desapropriação, desde que pago o preço ${ }^{87}$, visto que a terra foi transformada em mercadoria.

Ao mesmo tempo em que o Século XIX se despede e o Século XX é recepcionado com profundas mudanças no conteúdo do direito de propriedade, que deixa de ter o caráter exclusivista do período anterior, no Brasil está sendo introduzido no sistema jurídico o Código Civil de 1916, que entrou em vigor em 1917, marcado pelo caráter patrimonialista e exclusivista do direito de propriedade. Esse é o código que foi transformado numa espécie de "bíblia sagrada" do judiciário, que demarca "o conservadorismo dos magistrados, incubados em faculdades de Direito intelectualmente

\footnotetext{
${ }^{85}$ MARÉS, op. cit., p. 83.

${ }^{86}$ HESPANHA, Pedro. Com os pés na terra: práticas fundiárias da população rural portuguesa. Porto: Edições Afrontamento, 1994, p. 79-80.

${ }^{87}$ MARÉS, op. cit., p. 87.
} 
anquilosadas, dominadas por concepções retrogradas entre direito e sociedade; o desempenho rotinizado assente na justiça retributiva, politicamente hostil à justiça distributiva e tecnicamente despreparada para ela; uma cultura jurídica "cínica" que não leva a sério a garantia dos direitos". 88

Percebe-se que, mesmo considerada a função social e a necessidade de uma reforma agrária como uma pauta dos países capitalistas, o caráter patrimonialista da cultura política e jurídica dos países periféricos conduz à manutenção do sistema agro exportador através do latifúndio. Ao mesmo tempo em que, na Europa desenvolvida, as grandes lutas ideológicas marcadas por concepções antagônicas conduziam aquela parte o mundo à realização de uma ampla reforma agrária, com uma notável alteração do conteúdo do direito de propriedade, na América Latina "povos estavam sendo expulsos de suas terras e enfrentavam a bala e faconaço os invasores, em situação que fazia lembrar o que vivera a Europa pouco mais de um século antes. As populações moravam e produziam seu sustento nas terras, enquanto o Governo concedia títulos que possibilitavam aos novos 'proprietários' usarem a sua força ou a força pública para fazer valer o novo direito". ${ }^{89}$ Nota-se, assim, que a violência é a marca desse processo que mantém intocado o sistema de dependência dos países periféricos, incluídos nesta categoria os da América Latina.

Aos poucos, no entanto, as mudanças de concepção acerca do direito de propriedade se fazem sentir também na América Latina, a exemplo do México, Bolívia, Venezuela, Colômbia e Brasil. ${ }^{90}$ Tais mudanças, apesar de não terem sido acompanhadas de efetividade no sentido amplo do termo, no nosso entendimento tem um significado muito forte no sentido de permitir à sociedade e seus operadores ou atores jurídicos um instrumental que possa servir de suporte para exigir dos governos o cumprimento das políticas públicas em matéria de justiça social no campo.

\section{CONSIDERAÇÕES FINAIS}

\footnotetext{
${ }^{88}$ SANTOS, Boaventura Sousa [et al]. Os Tribunais na sociedade contemporânea. O caso português. Porto: Edições Afrontamento, 1996, p. 38.

${ }^{89}$ MARÉS, op. cit., p. 92.

${ }^{90}$ Considerado o limite deste artigo, não será possível uma abordagem mais detalhada de cada um dos países citados. Poderemos, em momento posterior, aprofundar estudos acerca da função social da propriedade.
} 
Com olhares voltados para o discurso sobre a propriedade, estabeleceu-se inicialmente um marco divisor entre a antiga e a moderna concepção do mencionado instituto jurídico. A modernidade provocou uma profunda ruptura com a fé religiosa, a tradição e o uso, que demarcaram as relações do homem com a natureza na antiguidade. ${ }^{91}$

No novo cenário, cujo ponto de partida é o Século XVII, são introduzidas significativas modificações no cotidiano das relações sociais, sendo o indivíduo proprietário alçado à condição de centralidade do relato político moderno. ${ }^{92}$

No discurso de Locke sobre a propriedade, esta é apresentada como uma grande obra cujo arquiteto é Deus. Este artífice construiu a obra e deu aos homens em comum, não havendo proprietário individual. Mas Locke justifica a transformação da natureza pelos homens, seres racionais que, através do trabalho, modificam o meio físico, possibilitando a apropriação individual daquela parte da natureza que foi transformada pelo trabalho. ${ }^{93}$

Essa nova concepção de propriedade ligada ao trabalho serve de fundamento para a criação da lei de terras em Portugal, ainda fundada no uso, situação que é alterada posteriormente, passando a prevalecer o modelo de propriedade como garantia e exclusividade. Essa nova caracterização da propriedade passa a constituir elemento fundamental dos ordenamentos jurídicos modernos.

No paradigma do Estado Moderno, cabe ao Judiciário a garantia do exercício desse direito, ainda que excluindo a imensa maioria do acesso, sem nenhuma preocupação também com os aspectos ecológicos nem tampouco com as condições de vida do trabalhador. Nas palavras de Marx, "quanto mais o trabalhador se desgasta trabalhando (ausarbeitet), tão mais poderoso se torna o mundo objetivo, alheio (fremde) que ele cria diante de si, tão mais pobre se torna ele mesmo, seu mundo interior, [e] tanto menos [o trabalhador] pertence a si próprio." 94

Por outro lado, ao mesmo tempo em que o modelo exclusivista de propriedade se consolida, idéias contrárias passam a influenciar significativa parcela da sociedade, gerando intensos conflitos, colocando em debate dois projetos contrapostos, vale dizer, o

\footnotetext{
91 FUSTEL DE COULANGES, Numa Denis (1830-1889). A cidade antiga. Tradução de Fernando de Aguiar. $4^{\mathrm{a}}$ ed. São Paulo: Martins Fontes, 1998, p. 56-69.

92 CAPELLA, Juan Ramón. Fruto Proibido: Uma aproximação histórico-teórica ao estudo do direito e do estado. Tradução: Gresiela Nunes da Rosa [et al]. Porto Seguro: Livraria do advogado, 2002.

${ }^{93}$ LOCKE, John. Da propriedade. In: LOCKE John. Dois tratados sobre o governo. Tradução Julio Fischer. São Paulo: Martins Fontes, 1998, p. 405-429.

${ }^{94}$ MARX, Karl. Trabalho estranhado e propriedade privada. In: ANTUNES, Ricardo (org.). A dialética do trabalho. São Paulo: Expressão Popular, 2004, p. 177.
} 
socialista e o capitalista. As pressões advindas de movimentos sociais na Europa, como dito antes, conduzem os países industrializados a implementar o Estado de Bem-Estar Social, introduzindo o conceito de função social da propriedade, conceito este que passou a ser incorporado às Constituições dos países da América Latina.

O conceito de função social da propriedade nasce como mecanismo para impor um limite não só no conteúdo, mas também na extensão da propriedade. Vale notar que essa questão do limite não é nova. Aristóteles, em seus diálogos com Sócrates e Platão já se preocupou com o número de propriedades que um homem deve ter. A seguinte passagem da obra do mencionado filósofo grego é ilustrativa: "Platão permite que a propriedade inteira de um homem tenha cinco vezes o tamanho original. Por que não estabelecer também um limite para o número de vezes em que as terras de um homem possam ser aumentadas?"95

As mudanças introduzidas no conceito de propriedade e incorporadas nas mais diversas Constituições não foram efetivadas nos países da semiperiferia e da periferia do sistema mundo, exercendo o Judiciário, nesses países, um importante papel na manutenção da propriedade da terra no seu sentido consolidado no século XIX.

O Brasil, após 500 anos de acumulação da propriedade da terra sob o domínio de poucos, com a Constituição Federal de 1988, inaugura o Estado Democrático de Direito, que inclui dentre seus fundamentos a dignidade da pessoa humana ( $\operatorname{art} .1^{\circ}$, III), constituindo como objetivos fundamentais, dentre outros, construir uma sociedade livre, justa e solidária (art. $\left.3^{\circ}, \mathrm{I}\right)$, erradicar a pobreza e a marginalização (art. $3^{\circ}$, III), promover o bem de todos, sem preconceitos de origem, raça, sexo, cor, idade e quaisquer outras formas de discriminação (art. $3^{\circ}$, IV).

No seu artigo $5^{\circ}$, XXII, a Carta Magna garante o direito de propriedade, mas logo em seguida, no inciso XXIII condiciona o exercício do mencionado direito ao cumprimento da função social. Nota-se, portanto, que o direito de propriedade e a função social são dois aspectos relevantes para entendermos a questão agrária no Brasil e os conflitos dela decorrentes.

A propriedade moderna nasceu exclusiva, tendo o proprietário o direito de usar, gozar e dispor da coisa da forma que lhe conviesse. Na qualidade de senhor de seus

\footnotetext{
${ }^{95}$ ARISTÓTELES. A política. São Paulo: Editora Nova Cultural Ltda, 1999, p. 183.
} 
bens podia destruir e degradar o meio ambiente. E foi assim que no Brasil os latifundiários sempre procederam. Por isso tanta degradação, tanta destruição e tanta concentração. ${ }^{96}$

Esse direito não mais existe. Todos os países do mundo mudaram suas leis. No caso brasileiro, a Constituição Federal de 1988 ao assegurar o direito de propriedade, limitou o debatido direito ao cumprimento da função social.

Mas afinal, quando é que podemos dizer que um imóvel está cumprindo a função social? A própria Constituição Federal responde a essa pergunta. Para o caso dos imóveis urbanos condiciona a propriedade ao cumprimento das exigências fundamentais de ordenação da cidade expressas no plano diretor $\left(\operatorname{art} .182, \S 2^{\circ}\right)$. Já no caso dos imóveis rurais, os requisitos da função social estão previstos no artigo 186 . Na forma do mencionado dispositivo a função social da propriedade é cumprida quando atende, simultaneamente, segundo critérios e graus de exigência estabelecidos em lei, aos seguintes requisitos: 1) aproveitamento racional e adequado; 2) utilização adequada dos recursos naturais disponíveis e preservação do meio ambiente; 3) observância das disposições que regulam as relações de trabalho; 4) exploração que favoreça o bem-estar dos proprietários e dos trabalhadores.

A Constituição, ao garantir o direito de propriedade, não afasta do mencionado direito questões relevantes como os respeito ao meio ambiente e as condições humanas. Não podemos separar direito de propriedade da função social, assim como não podemos separar função, que significa, dentre outros aspectos, a preservação do meio ambiente e a garantia dos direitos fundamentais dos trabalhadores e de todos os povos. Ausentes tais requisitos e uma política séria de reforma agrária, certamente continuaremos exibindo os piores índices de desenvolvimento humano, apesar de ainda sermos um dos poucos países mais ricos do mundo.

\title{
THE POLITICAL AND PHILOSOPHICAL FUNDAMENTALS OF THE MODERN PROPERTY, ITS RUPTURES AND SOCIAL FUNCTION
}

\author{
Cloves dos Santos Araújo
}

\begin{abstract}
${ }^{96}$ Sobre o assunto, vale consultar GUIMARÃES, Alberto Passos. Quatro Séculos de Latifúndio. Rio de janeiro: Paz e Terra, 1968.
\end{abstract}


The occidental mordernity, breaching with the faith, the tradition and collective forms of relationship with the land, introduces in the legal systems a concept of property centered not in the collective use, as it happened in the antiquity, but, over all, in the individual appropriation and the mercantilism. John Locke, using the philosofy as his main tool, looking for justify this way of nature's appropriation by the individual, chooses the work as conducting wire. The property, with the modern codification, starts to incorporate the legal systems as an individual and exclusive right. However, from the second decade of Century XX, the property has its content modified, starting to have the incubency to take care of the social function.

Keywords: Modernity. Property. Work. Social function.

\section{REFERÊNCIAS}

ARISTÓTELES, A política. São Paulo: Editora Nova Cultural Ltda, 1999.

BALDEZ, Miguel Lanzellotti. A terra no campo: a questão agrária. In: MOLINA, Mônica Castagna, SOUSA JÚNIOR, José Geraldo e TOURINHO NETO, Fernando da Costa (org.). Introdução crítica ao direito agrário. Série o direito achado na rua, v. 3. Brasília: Editora UNB, 2002, p. 95-106.

CAPELLA, Juan Ramón. Fruto Proibido: Uma aproximação histórico-teórica ao estudo do direito e do estado. Tradução: Gresiela Nunes da Rosa [et al]. Porto Alegre: Livraria do Advogado, 2002.

CHAUÍ, Marilena. Convite à filosofia. São Paulo: Editora Ática, 1995, p. 90-98.

COMPARATO, Fabio Konder. Direitos e deveres fundamentais em matéria de propriedade. In: STROZAKE, Juvelino José (org.). A questão agrária e a justiça. São Paulo: Revista dos Tribunais, 2000, p. 130-147.

FACHIM, Luiz Edson. A justiça dos conflitos agrários no Brasil - IN: STROZAKE, Juvelino José. A questão agrária e a justiça. São Paulo: Revista dos Tribunais, 2000.

A reforma no direito brasileiro: novas notas sobre um velho debate no direito civil. In: Noticia do direito brasileiro. Nova série, n. 10. Universidade de Brasília, 2004, p. 61-68.

. O Poder Judiciário e a questão agrária. Palestra realizada por ocasião do VIII Encontro da Rede Nacional de Advogados Populares - RENAP, Brasília, 12 dez. 2003.

. Teoria crítica do direito civil. Rio de Janeiro: Renovar, 2003.

FUSTEL DE COULANGES, Numa Denis (1830-1889). A cidade antiga. Tradução de Fernando de Aguiar. $4^{\mathrm{a}}$ ed. São Paulo: Martins Fontes, 1998, p. 56-69. 
GUIMARÃES, Alberto Passos. Quatro Séculos de Latifúndio. Rio de janeiro: Paz e Terra, 1968.

HESPANHA, Antônio Manuel. O direito e a imaginação antropológica nos primórdios da era moderna. In: Novos estudos CEBRAP, n. 59, mar. 2001, p. 137-152.

HESPANHA, Pedro. Com os pés na terra: práticas fundiárias da população rural portuguesa. Porto: Edições Afrontamento, 1994, p. 79-80.

LOCKE, John. Da propriedade. In: LOCKE John. Dois tratados sobre o governo. Tradução Julio Fischer. São Paulo: Martins Fontes, 1998, p. 405-429.

LYRA FILHO, Roberto. O quer é direito. São Paulo: Brasiliense, 1982.

MARÉS, Carlos Frederico. A função social da terra. Porto Alegre: Sergio Antônio Fabris Editor, 2003.

MARX, Karl. Trabalho estranhado e propriedade privada. In: ANTUNES, Ricardo (org.). A dialética do trabalho. São Paulo: Expressão Popular, 2004, p. 173-195.

PRESSBURGER, T. Miguel. Terra, propriedade, reforma agrária e outras velharias. In: VARELLA, Marcelo Dias (org.). Revoluções no campo jurídico. Joinville: Oficina de Comunicações Editora, 1998, p. 297-310.

ROUSSEAU, Jean Jacques. Discurso sobre a origem e fundamentos da desigualdade ente os homens. $2^{\mathrm{a}}$ ed., Portugal: Publicações Europa América.

SANTOS, Boaventura de Sousa [et al]. Os tribunais na sociedade contemporânea. O caso português. Porto: Edições Afrontamento, 1996.

SANTOS, Fábio Alves dos. Direito agrário: política fundiária no Brasil. Belo Horizonte: Del Rey, 1995.

SILVEIRA, Domingos Sávio Dresch da. A propriedade agrária e suas funções sociais. In: SILVEIRA, Domingos Sávio Dresch da (et al, org.). O direito agrário em debate. Porto Alegre: Livraria do Advogado, 1998.

SOUSA JÚNIOR, José Geraldo de. O direito achado na rua: terra, trabalho, justiça e paz. Introdução crítica ao direito agrário. In: MOLINA, Mônica Castagna, SOUSA JÚNIOR, José Geraldo de, TOURINHO NETO, Fernando da Costa (org.). Introdução crítica ao direito agrário. Brasília: Editora UnB, 2002 (1).

THOMPSON, E. P. Senhores e caçadores. A origem da lei negra. Tradução, Denise Bottmann. Rio de Janeiro: Paz e Terra, 1987.

VARELLA, Marcelo Dias. Introdução ao direito à reforma agrária: o direito face aos novos conflitos sociais. Leme, SP: LED - Editora de Direito Ltda, 1998.

WARAT, Luis Alberto. A ciência jurídica e seus dois maridos. $2^{\mathrm{a}}$ ed. Santa Cruz do Sul: EDUNISC, 2000. 